Original Research Paper

\title{
Hazards from Pyroclastic Density Currents at Mount Bamenda (West-Cameroon, Cameroon Volcanic Line): Mapping and Assessment by AMS Method
}

\author{
${ }^{1}$ Merlin Gountié Dedzo, ${ }^{2}$ Pierre Kamgang, ${ }^{3}$ Emmanuel Njonfang and ${ }^{4}$ Ghislain Zangmo Tefogoum \\ ${ }^{1}$ Department of Life and Earth Sciences, \\ Higher Teachers' Training College, University of Maroua, P.O. Box 55, Maroua, Cameroon \\ ${ }^{2}$ Department of Earth Sciences, University of Yaoundé I, P.O. Box 812, Yaoundé, Cameroon \\ ${ }^{3}$ Laboratory of Geology, Higher Teachers' Training College, \\ University of Yaoundé I, Cameroon, P.O. Box 47, Yaoundé I, Cameroon \\ ${ }^{4}$ Faculty of Sciences, University of Maroua, P.O. Box 46, Maroua, Cameroon
}

Article history

Received: 29-01-2015

Revised: 29-03-2015

Accepted: 14-09-2015

Corresponding Author: Merlin Gountié Dedzo Department of Life and Earth Sciences, Higher Teachers'

Training College, University of Maroua, P.O. Box 55, Maroua,

Cameroon

Tel: +237 $675088586 / 694028$ 347

Email: merlin.gountie@gmail.com

\begin{abstract}
Hazards related to pyroclastic density current continue to raise victims on many volcanoes in our planet. The Cameroon is not spared to this type of hazard because deposits of pyroclastic flows and surges are found on Mount Bamenda; products of this volcano are relatively young (27-0 Ma). Besides Mount Bamenda, Mounts Bambouto and Oku are the only volcanoes located in the central part of the Cameroon Volcanic Line where these ignimbritic deposits are found. Several factors highlight dangerousness and damage that can cause ignimbritic flows on the flanks of this volcano. This is essentially the high aspect ratio of these ignimbrites, the important population (about 750,000 people) that lives on the slopes and around the volcano. In order to have an idea of a nowadays ignimbritic eruption scenario on Bamenda volcano, the Anisotropy of Magnetic Susceptibility (ASM) method is used in this study to highlight the palaeoflow in ancient deposits of ignimbrites which are mostly discontinuous and isotropic. Results of AMS study are used to produce map of hazards and assess risks that may be related with such eruptions in Bamenda volcano.
\end{abstract}

Keywords: Bamenda Volcano, Ignimbritic Eruption, Paleoflow, Mapping and Assessment, AMS

\section{Introduction}

The Cameroon Volcanic Line (CVL) is characterized by alignment of oceanic and continental volcanic massifs and anorogenic plutonic complexes extending from Pagalu Island in the Atlantic Ocean to Chad with $\mathrm{N} 30^{\circ} \mathrm{E}$ general orientation (Fig. 1). Volcanism along this line began in the Eocene by the formation of Bamoun plateau between 51.8 and 46.7 Ma (Moundi et al., 2007) and Mount Bangou between 44.7 and 43.1 Ma (Fosso et al., 2005) and continues until the present day on Mount Cameroon (Suh et al., 2003). The products of the CVL volcanism are mainly rhyolites, phonolite, trachyte and basalt. Welded and non-welded ignimbritic deposits are found only in the continental sector of the CVL, particularly in the Mts
Bambouto and Bamenda (Fig. 2). Deposits of limited extension have been also described in Nkogam (Kamgang, 1986), Oku (Dunlop, 1983 and Lissom, 1991) and Nganha volcanoes (Nono et al., 1994).

The Bamenda volcano covers an area of about 600 $\mathrm{km}^{2}$ and culminates at $2621 \mathrm{~m}$ (Bambili Lake borders). It is characterized by two elliptically shaped calderas (Fig. 2): Santa-Mbu caldera $(6 \times 4 \mathrm{~km})$ and Lefo caldera $(4 \times 3 \mathrm{~km})$. Their floor located respectively at 550 and $400 \mathrm{~m}$ is composed mainly of trachytic domes, which are also abundant on the external slopes of the massif. In addition to felsic, intermediate and mafic lavas, numerous outcrops of ignimbritic deposits are found in mount Bamenda. The massifs lay on a granitic PanAfrican basement (Toteu et al., 2001; Nzolang et al., 2003). According to Kamgang et al. (2007; 2008), 
intermediate and felsic lavas (27.40-18.98 Ma) are made of rhyolites, trachytes, benmoreites and mugearites. Mafic lavas (hawaiites, basalts and basanites) are dated from 17.4 Ma to the present. The presence of pyroclastic density currents deposits justify the dangerousness of this volcano because it is still considered as an active volcano in the CVL with the basalts recently dated to $0 \mathrm{Ma}$ (Kamgang et al., 2007).

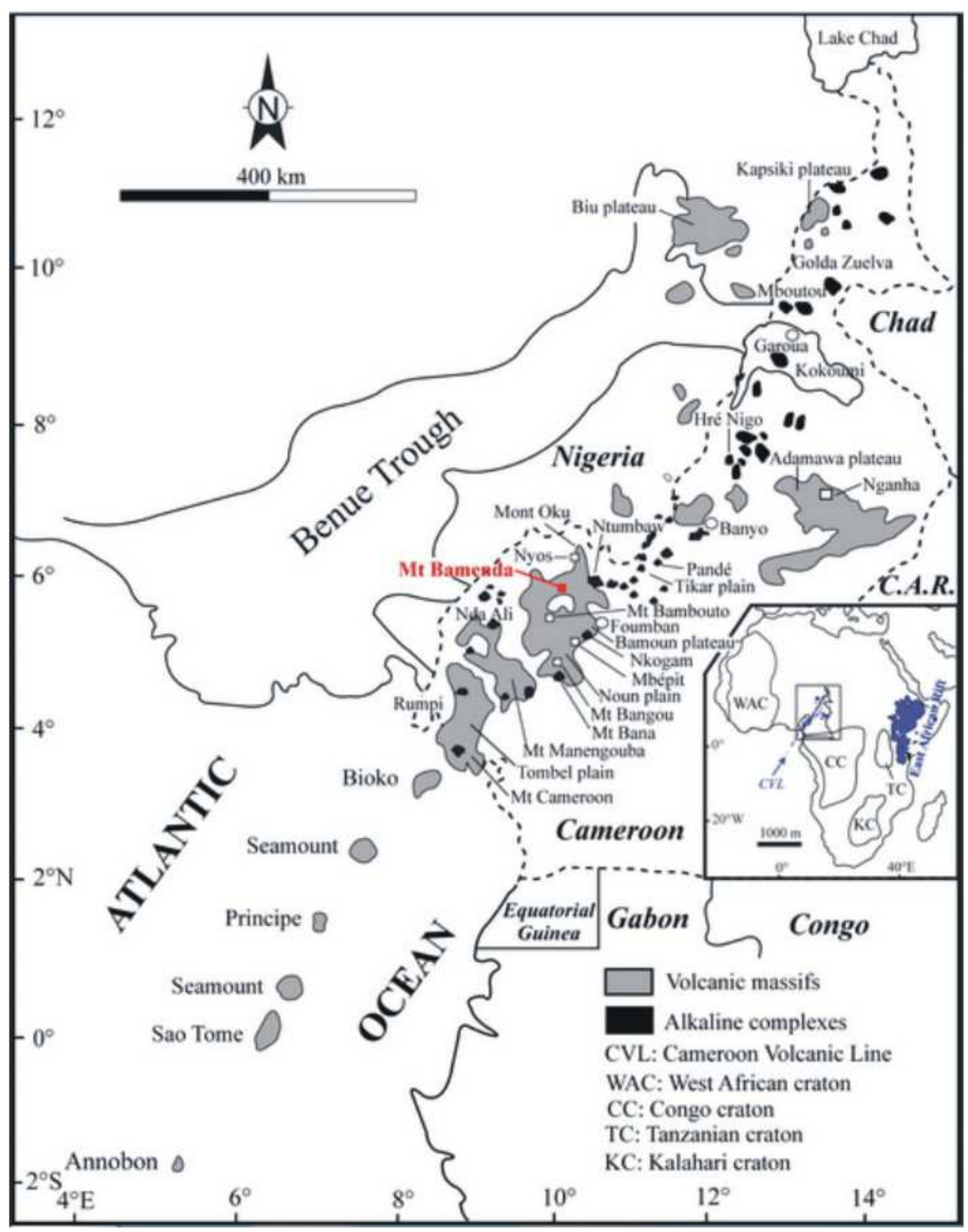

Fig. 1. Location map of the Cameroon Volcanic Line (CVL) with the main volcanic centres of the CVL with the plutonic complexes 


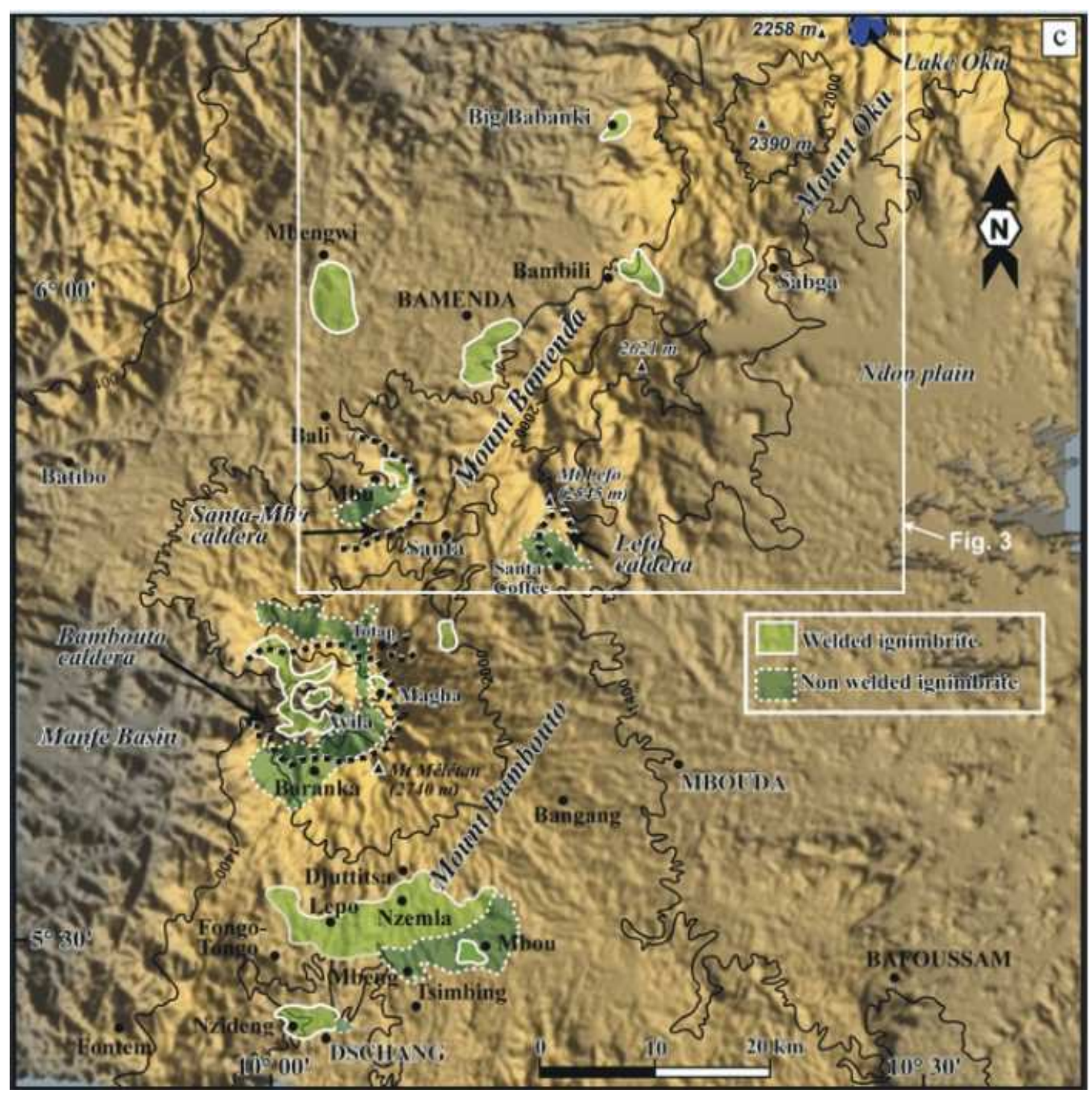

Fig. 2. Digital Elevation Model (DEM) of Mount Bamenda and the close surroundings presenting the ignimbritic outcrops: Shuttle Radar Topography Mission (SRTM, NASA)

\section{Pyroclastic Density Currents Deposits}

Pyroclastic Density Currents (PDC) are volcanic emissions that lead to the formation of ignimbrite deposits. They constitute an inhomogeneous mixture of volcanic particles (lava fragments, ash and block) and gas that flow according to their density relative to the surrounding fluid and due to Earth's gravity (Branney and Kokelaar, 2002; Schminke, 2004). Speeds (up to $300 \mathrm{~km} / \mathrm{h}$ ) and temperatures (up to $600-700^{\circ} \mathrm{C}$ ) of these flows are generally highon the earth surface (Wilson and Houghton, 2000). PDC are mainly controlled by gravity (Carey, 1991; Druitt, 1998a; Belousov et al., 2002; Burgisser and Bergantz, 2002) and commonly indicating a turbulent regime (Fisher, 1990; Carey,
1991; Dellino and La Volpe, 2000; Valentine and Fisher, 2000). A pyroclastic flow is diluted when he have a solid volume concentration equal or less than a few percent; a concentrated suspension or of high concentration will thus have a concentration of several percent or several tens of percent (Choux, 2001). PDC are subdivided on the basis of textural characteristics of the deposits, into two sub-groups which are either two particular phenomena, separated by a leap concentration (Walker, 1983; Wilson, 1997) or two extremes of a single continuous process (Fisher and Schmincke, 1984; Cas and Wright, 1987; Druitt, 1998b): Pyroclastic surges and flows.

Pyroclastic surges are diluted concentration flows whose stratified deposits drape topography. Pyroclastic 
flows are denser than surges and generally form more massive deposits, poorly sorted, filling the valleys. Surges can be associated with a pyroclastic flow, located at the periphery of this flow or generated by ash cloud surmounting it (case of Mt St Helens, Mellors et al. (1988) and the Soufriere Hills volcano, Calder et al. (1999).

On Mount Bamenda, deposits of these two types of flows have been identified. They can originate by fountain-like collapse of parts of an eruption column following explosive fragmentation of magma and rock in a volcanic conduit, or from laterally inclined blasts, or from hot avalanches derived from lava domes. They can transport large volumes of hot debris rapidly for many kilometers across the ground and they constitute a lethal and destructive volcanic hazard. Ground-hugging pyroclastic density currents produce a buoyant counterpart, known as a phoenix cloud or co-ignimbrite ash plume, which can carry ash and aerosols into the stratosphere and so cause significant climatic perturbation. Most processes within pyroclastic density currents are impossible to observe and so are commonly inferred from the associated deposits.

\section{Aim of Study}

During the past years, many people have been killed on volcanoes by relatively small eruptions that otherwise represented no hazard to nearby populated and cultivated areas. Pyroclastic surges and flows have caused about 55,000 deaths since 1600 A.D. (about $48 \%$ of all volcano-related fatalities). The Bamenda volcano being still considered as active can potentially cause massive damage in case of an eruption occurred, because in the past, violent eruptions have set up significant ignimbrite deposits on the slopes of the volcano. The purpose of this paper is to map and assess pyroclastic density currents hazards at Mount Bamenda which are the most disastrous in terms of possible volcanic processes in this region. To achieve this goal, anisotropy of magnetic susceptibility has been used to determine flow directions in ancient ignimbritic deposits which are visually nearly isotropic in most outcrops. Magnetic fabrics of ignimbrites help us to determine palaeoflow directions of pyroclastic density currents, to then reassemble discontinuous deposits into their original ignimbrite sheets and to identify their source. Such reconstructions allow us to plan future potential ignimbritic eruption scenarios and draw a hazard map of pyroclastic density currents in the Bamenda volcano.

\section{Petrography of Ignimbritic Deposits}

Ignimbrites are predominantly observed in the central part of the CVL; they are concentrated principally in Mount Bamenda and its SW extension (Mount Bambouto) (Fig. 2). The ignimbrites of Bamenda volcano constitute roughly $7.5 \%$ of the massif representing about $45 \mathrm{~km}^{2}$ with a volume estimated at $6.3 \mathrm{~km}^{3}$ (Fig. 3). Ignimbrites of Mt Bamenda lie on a granito-gneissic basement and are covered by old lateritized basalt as in the case of Mounts Bambouto. The aspect ratios of these ignimbrites are generally high $\left(2.77 \times 10^{-2}\right.$ to $\left.7.23 \times 10^{-2}\right)$. According to Branney and Kokelaar (2002) classification, these ignimbrites consist of massif lithic breccias $(\mathrm{mlBr})$ and massif lapilli tuff (mlT).

\section{The Welded Ignimbrites}

The welded ignimbrites outcrop as sheets, metric and decimetric blocks balls. The color of rock and the proportions of lithic fragments and minerals are variable depending of the type of the facies identified at Bamenda, Mbu, Mbengwi, Bambili, Sabga and Big Babanki (Gountié Dedzo et al., 2011).

\section{The Ignimbrites of Mbengwi, Mbu and Bamenda,}

The ignimbritic deposits of Mbengwi, Bamenda and Mbu cover an area of approximately 12,11 and $3 \mathrm{~km}^{2}$ respectively with thickness varying from 50 to $200 \mathrm{~m}$. In the different locality, the deposits lie on syenitic and granitic basement rock (Fig. 4a-c). The mlT facies of Bamenda (Fig. 5a) consist of two light gray cooling units covered by $\mathrm{mlBr}$ facies while that of $\mathrm{Mbu}$ is represented by a single dark gray cooling unit on which lie a non-welded mlT covered by an $\mathrm{mlBr}$ facies. The whole unit of ignimbrite of Mbengwi is constituted by Brlm facies (Fig. 5b). In Bamenda, the fiammes (6 to $10 \%$ ) are mostly black and usually flattened, giving to the rock a eutaxitic texture. Lithics (12 to $15 \%$ ) of mlT facies are commonly rhyolites, granites and trachytes; in brecciated zones of the ignimbritic deposit, their proportions reach 35 to $40 \%$. The matrix consist of clinopyroxene (1\%), biotite (1 -2\%), plagioclase (1-2\%), oxides (1-3\%), quartz (1-3\%) and alkali feldspar (5-10\%; sanidine: $\left.\mathrm{Ab}_{62-58} \mathrm{Or}_{42-38}\right)$.

\section{The Ignimbrites of Big Babanki, Sabga and Bambili}

The ignimbritic deposit of Big Babanki, Sabga Bambili and cover a surface of $3 \mathrm{~km}^{2}, 5 \mathrm{~km}^{2}$ and $6 \mathrm{~km}^{2}$ respectively. These deposits form small outcrops with thickness varying from 65 from $120 \mathrm{~m}$ (Fig. 4d-f). The remnant blocks (up to $7.5 \times 12 \mathrm{~m}$ ) of ignimbrites (surge deposits) (Fig. 5c) are also observed at Bambili (Gountié Dedzo et al., 2015). They lie on a basement rock made of migmatite, schist and granite. The welded mlT ignimbrite of Bambili possess trace of rubefaction in places and characterized by two cooling units (dark-grey and whitish) while the ignimbrite of Big Babanki is represented only by one whitish unit; the two outcrops are covered in places by a $\mathrm{mlBr}$ facies. The ignimbrite of Sabga (Fig. 5d) is also a welded mlT constituted by one dark-gray unit covered by one light grey unit. 


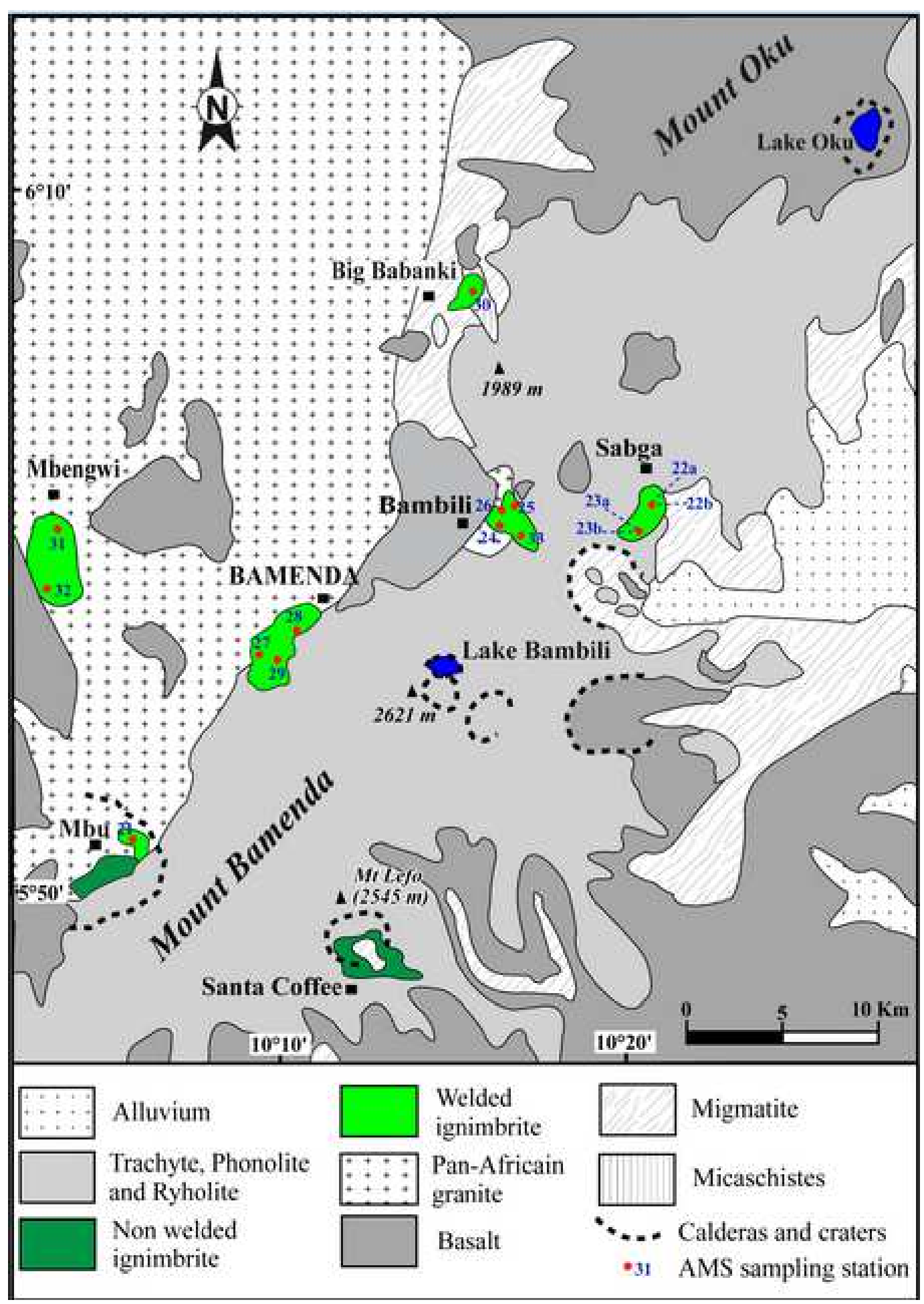

Fig. 3. Geologic sketch map of Mount Bamenda showing the AMS sampled stations

The fiammes (25-40\%) are generally distorted in the basal parts of the outcrops. Enclaves of rocks (8-15\%) consist of granites vitrophyre, trachytes, ignimbrites and rhyolites; in $\mathrm{mlBr}$ facies of Bambili, they represent 60 to $70 \%$ where there are predominantly enclaves of black vitrophyre. The matrix is devitrified and consist of alkali feldspar (5-10\%; sanidine: Clinopyroxene (1\%), biotite (1\%), oxides (1-3\%), plagioclase (1-3\%) and $\left.\mathrm{Ab}_{58-57} \mathrm{Or}_{57-41}\right)$, quartz $(2-3 \%)$. 


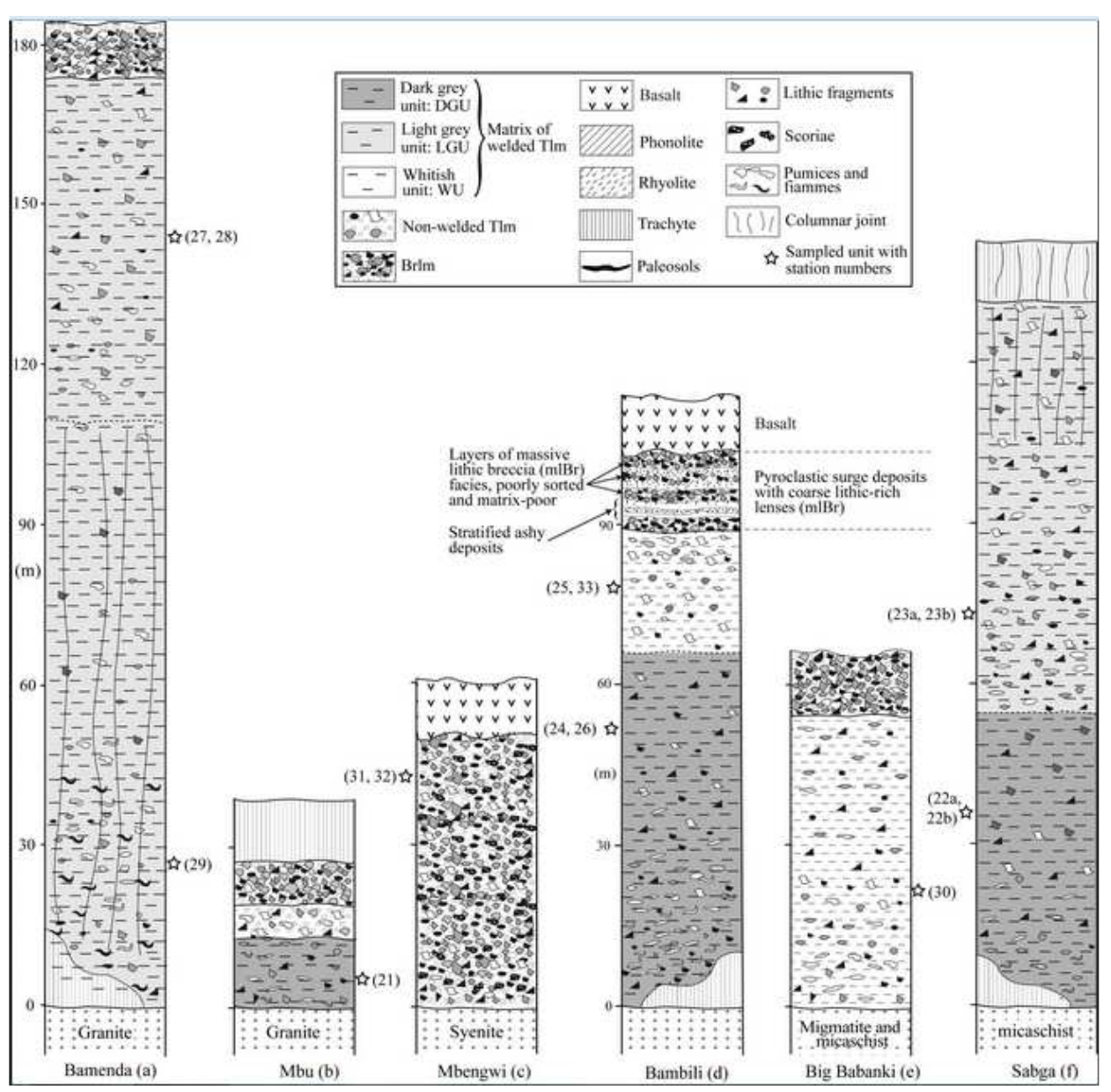

Fig. 4. The Mount Bamenda ignimbrites: Stratigraphic sections in some localities (modified from Gountié Dedzo et al., 2011)

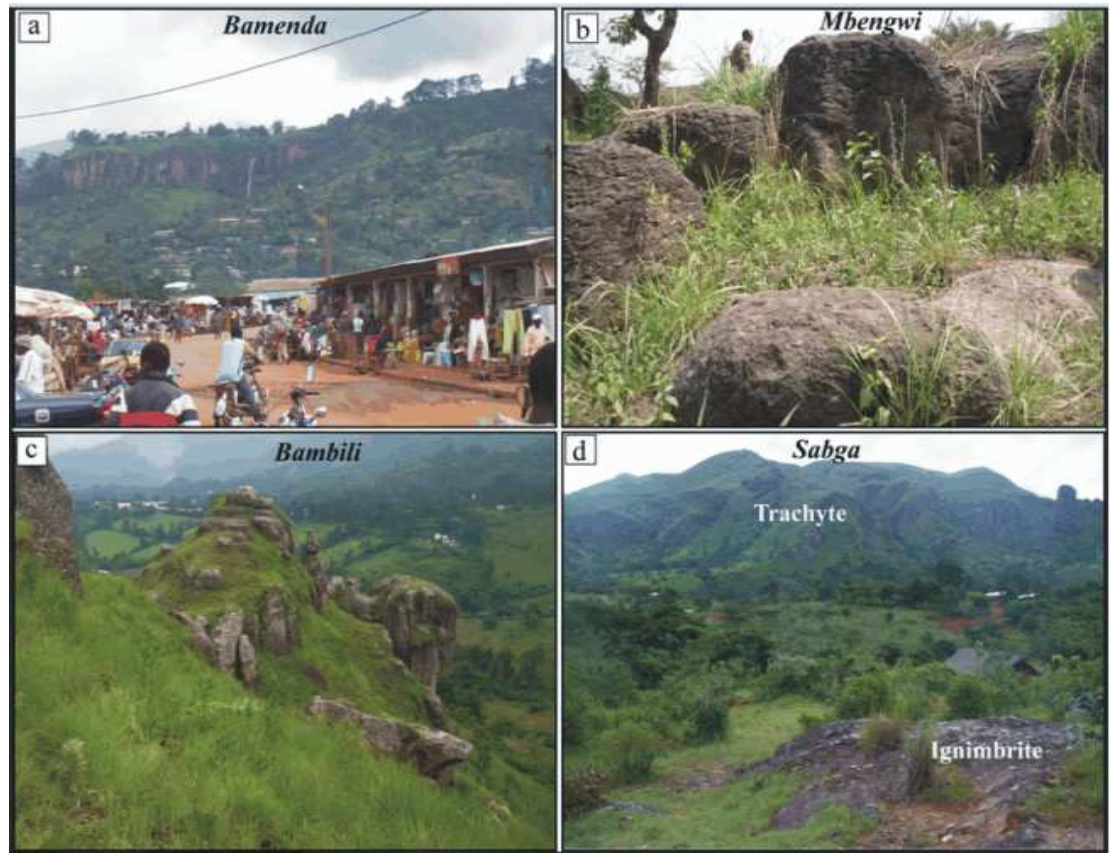

Fig. 5. Ignimbrite outcrops in some localities of Mount Bamenda 
Table 1. Result of magnetic studies of Bamenda volcano ignimbrites. N: number of samples for the site; sample with star represent rejected sample due to high within site dispersion; Km: mean magnetic susceptibility; P\%: total anisotropy percentage; L\%: linear anisotropy percentage; F\%: planar anisotropy percentage; T: Jelinek's shape parameter (Jelinek, 1981 ); $\mathrm{K}_{1}, \mathrm{~K}_{2}$ and $\mathrm{K}_{3}$ are the maximum, intermediate and minimum susceptibility intensities respectively; D: Declination in degrees; I: Inclination in degrees

\begin{tabular}{|c|c|c|c|c|c|c|c|c|c|c|c|c|c|c|c|}
\hline \multirow[b]{3}{*}{ Locality } & \multirow[b]{3}{*}{ Site } & \multirow[b]{3}{*}{ Lon. $\left(^{\circ}\right)$} & \multirow[b]{3}{*}{ Lat. $\left(^{\circ}\right)$} & \multirow{2}{*}{\multicolumn{6}{|c|}{ AMS parameters }} & \multicolumn{6}{|c|}{ Means eingenvectors } \\
\hline & & & & & & & & & & \multicolumn{2}{|l|}{$\mathrm{K}_{1}$} & \multicolumn{2}{|l|}{$\mathrm{K}_{2}$} & \multicolumn{2}{|c|}{$\mathrm{K}_{3}$} \\
\hline & & & & $\mathrm{N}$ & $\mathrm{Km}(\mu \mathrm{SI})$ & $\mathrm{P} \%$ & $\mathrm{~L} \%$ & $\mathrm{~F} \%$ & $\mathrm{~T}$ & $\mathrm{D}$ & I & $\mathrm{D}$ & I & $\mathrm{D}$ & $\mathrm{I}$ \\
\hline \multirow[t]{3}{*}{ Bamenda } & GM27 & 10.15417 & 5.96444 & 23 & 147.3 & 0.7 & 0.3 & 0.4 & 0.1 & 142 & 2 & 233 & 11 & 45 & 79 \\
\hline & GM28 & 10.17389 & 5.95806 & 24 & 88.9 & 0.7 & 0.0 & 0.7 & 0.9 & 254 & 35 & 14 & 35 & 134 & 36 \\
\hline & GM29 & 10.16500 & 5.94500 & 22 & 375.5 & 0.6 & 0.4 & 0.2 & -0.3 & 278 & 81 & 43 & 6 & 134 & 8 \\
\hline Mbu & GM21 & 10.09472 & 5.85611 & 20 & 911.1 & 0.8 & 0.3 & 0.4 & 0.1 & 213 & 13 & 307 & 13 & 79 & 71 \\
\hline \multirow[t]{2}{*}{ Mbengwi } & GM31 & 10.06222 & 6.00056 & 33 & 2062.5 & 0.2 & 0.0 & 0.1 & 0.5 & 182 & 24 & 274 & 4 & 12 & 66 \\
\hline & GM32 & 10.05528 & 5.97917 & 32 & 725.6 & 1.4 & 0.1 & 1.2 & 0.8 & 197 & 1 & 100 & 13 & 310 & 87 \\
\hline \multirow[t]{4}{*}{ Bambili } & GM24 & 10.27944 & 6.00417 & 24 & 3253.2 & 0.2 & 0.0 & 0.2 & 0.6 & 315 & 2 & 45 & 6 & 202 & 84 \\
\hline & GM26 & 10.27139 & 6.01333 & 12 & 2579.5 & 0.2 & 0.1 & 0.1 & 0.0 & 50 & 26 & 144 & 8 & 249 & 62 \\
\hline & GM25* & 10.27278 & 6.00694 & 32 & 66.3 & 0.4 & 0.2 & 0.2 & 0.0 & 144 & 89 & 282 & 1 & 12 & 1 \\
\hline & GM33 & 10.27139 & 6.00944 & 27 & 66.6 & 0.1 & 0.1 & 0.1 & 0.1 & 39 & 84 & 290 & 2 & 199 & 6 \\
\hline \multirow[t]{4}{*}{ Sabga } & GM22a & 10.33944 & 6.01917 & 11 & 1220.6 & 1.7 & 0.7 & 1.0 & 0.2 & 315 & 32 & 73 & 37 & 197 & 37 \\
\hline & GM22b & 10.33944 & 6.01917 & 9 & 1143.0 & 1.6 & 0.5 & 1.1 & 0.4 & 128 & 20 & 241 & 47 & 23 & 36 \\
\hline & GM23a & 10.33833 & 6.00778 & 7 & 391.9 & 0.5 & 0.3 & 0.1 & -0.3 & 221 & 8 & 340 & 73 & 129 & 15 \\
\hline & GM23b & 10.33833 & 6.00778 & 9 & 379.8 & 0.5 & 0.2 & 0.3 & 0.0 & 225 & 6 & 116 & 73 & 317 & 16 \\
\hline Big-Babanki & GM30 & 10.25944 & 6.12056 & 12 & 55.5 & 0.5 & 0.2 & 0.3 & 0.0 & 56 & 6 & 326 & 0 & 235 & 84 \\
\hline
\end{tabular}

\section{The Non-Welded Ignimbrites}

The non-welded ignimbritic deposits (about $5 \mathrm{~km}^{2}$ ) outcrop in the Santa-Mbu and Lefo caldera at Santa Coffee and Ndzah. They lie on a basement rock consisting of micaschist and covered by trachytic flow in the Lefo caldera. Their precise thickness $(>15 \mathrm{~m})$ is difficult to evaluate because of the profuse vegetation and uneven topography. The rock is very powdery and consists of enclaves (15-25\%) mainly trachytic with minor percentage of rhyolite, ignimbrite, obsidian and granite fragments. The average size of these enclaves is $3 \times 2.3 \mathrm{~cm}$; few enclaves reached $1.5 \times 2.4 \mathrm{~m}$; they have characteristics close to co-ignimbritic breccias as in Bambouto volcano. Probably due to the very advanced state of alteration in these deposits, the proportion of accretionary lapilli are low $(<5 \%)$. There is presence of feldspar, quartz and remnants fragments of pumices in the ashy matrix of deposits.

\section{Sampling Method and AMS Measurements}

The response to an applied magnetic field on a material or rock refers to Magnetic Susceptibility (MS). The main element responsible for the magnetization is iron. Anisotropy of low field MS is a multipurpose petrofabric instrument. AMS predominantly defines grain-shape anisotropy for magnetite; it's also expresses crystallographic control on magnetic properties for other minerals. We may therefore, infer the orientationdistribution of a dominant mineral from the AMS of a rock. Flow directions from pyroclastic deposits, magma and current directions from sediment, can record by AMS main directions. In this study, AMS is applied on ignimbrites with a view to reconstitute palaeoflow directions of pyroclastic current. All measurements were made in Géosciences Environnement Toulouse (GET) laboratory at Paul Sabatier University (Toulouse, France). Sampling of the Bamenda ignimbritic deposits was realized on 15 sites (Fig. 3) using a portable, drillapparatus with a non-magnetic diamond-tipped drill bit. At each AMS station, a maximum of 9 oriented cores were collected in a surface covering about 6 to $12 \mathrm{~m}^{2}$. Evidence of rheomorphic flow or secondary flow (Wolff and Wright, 1981) that might have modified their primary emplacement magnetic fabric was not identified in the studied rocks. Samples were then oriented (azimuth/dip) using magnetic compass and carefully numbered. Each core sample was cut into $22 \times 25 \mathrm{~mm}$ cylinder specimens in laboratory, using a diamond tipped, non-magnetic saw blade. Two to four specimens per core sample were obtained, hence a total of 297 specimens. AMS data were acquired using a Kappabridge susceptometer (KLY-3S, Agico, Czech Republic; operating at low alternating field $\left(4 \times 10^{-4} \mathrm{~T}\right.$ at $920 \mathrm{~Hz}$ ) with a sensitivity of about $2 \times 10^{-7} \mathrm{SI}$, allowing anisotropy discrimination below $0.2 \%$ over a wide range of susceptibility. This method measures the orientation of the magnetic carriers (minerals) in a rock which help to regenerate ancient flow directions. The MS can also be measured in different directions and the results are usually expressed in terms of an ellipsoid characterized by the maximum $\left(\mathrm{K}_{1}\right)$, intermediate $\left(\mathrm{K}_{2}\right)$ and minimum 
$\left(\mathrm{K}_{3}\right)$ susceptibility directions. The anisotropy of the principal susceptibility axes is commonly considered to be inherited from the mechanism of emplacement and can be used to rebuild ancient flow directions in ignimbrites lavas and intrusions. The small axis $\mathrm{K}_{3}$ (minimum susceptibility) is the foliation pole, i.e., the normal to the plane of magnetic foliation; the long axis $\mathrm{K}_{1}$ (maximum susceptibility) defines the magnetic lineation, meanwhile $\mathrm{K}_{2}$ is the mean susceptibility. The arithmetic mean of the lengths of the principal axes $(\mathrm{Km}=[\mathrm{K} 1+\mathrm{K} 2+\mathrm{K} 3] / 3)$ is the mean MS $(\mathrm{Km})$. The method also quantifies the anisotropy percentage achieved by the relation: $\mathrm{P} \%=[(\mathrm{K} 1 / \mathrm{K} 3)-1] \times 100$. In addition, the linear ( $\mathrm{L} \%)$ and planar ( $\mathrm{F} \%)$ anisotropies are also provided by equations: $\mathrm{L} \%=[(\mathrm{K} 1 / \mathrm{K} 2)-1]$ $\times 100$ and $\mathrm{F} \%=[(\mathrm{K} 2 / \mathrm{K} 3)-1] \times 100$. The $\mathrm{T}$ parameter of Jelinek (1981) expressed by $\mathrm{T}=\left(2 \ln \mathrm{K}_{2}-\ln \mathrm{K}_{1^{-}}\right.$ $\left.\ln K_{3}\right) /\left(\ln K_{1}-\ln K_{3}\right)$ characterizing the shape of the MS ellipsoid; its ranging from +1 for oblate ellipsoid to -1 for prolate ellipsoid. $\mathrm{T}$ values between -0.5 and +0.5 are characterized by triaxial ellipsoids.

Since the early work of Ellwood (1982), several studies have used AMS in an attempt to locate source vents of large ignimbrites. Some authors (MacDonald and Palmer, 1990; Seaman et al., 1991) compared AMS data from ignimbrites with petrographic and field observations and recognized that AMS provides a precise and significantly faster means of approximating the transport direction of ignimbritic deposits than techniques based on macroscopic examination. It is established that the heterogeneous character of an ignimbritic deposits does not really affect the AMS fabric and that this method provides a realistic indication of the flow direction (Wolff et al., 1989). Results of previous MS studies that have inferred flow patterns for ignimbritic deposits propose that the alignment and distribution of magnetic grains produces the anisotropic magnetic fabric (Wolff et al., 1989; Palmer and MacDonald, 1999). Magnetic lineations and foliations in ignimbrites arise as a consequence of alignment of magnetic mineral grains parallel to the direction of flow and the rotation of somewhat elongate to sub-equant magnetic grains so that their long dimension approximately parallels the direction of flow (Ellwood, 1982; Knight et al., 1986). The mean magnetic foliation plane (characterized by $\mathrm{K}_{2}-\mathrm{K}_{1}$ axes) is perpendicular to the $K_{3}$ axis and estimates the flow plane, for a normal magnetic fabric. Nevertheless, the plane of magnetic foliation frequently differs in orientation (imbrication angle) comparative to the flow plane (Ellwood, 1982; Knight et al., 1986) and dips in a direction opposite to the direction of flow. The imbrication dip direction is inferred to point in direction of the source area (Fig. 6b). The $\mathrm{K}_{1}$ axis is usually interpreted to be parallel to the flow direction and thus plunges towards the source
(Knight et al., 1986). The use of the $\mathrm{K}_{1}$ axis alone as a proxy for flow direction is not always reliable (Seaman et al., 1991; Hillhouse and Wells, 1991; Ort, 1993; Le Pennec et al., 1998) and a different methodology must be used to interpret the magnetic data. The imbrication angle of the magnetic foliation plane, which equivalents the deviation of the $\mathrm{K}_{3}$ axes from the normal to the macroscopic flow plane, offers another method to distinguish the flow direction of ignimbrite (Henry, 1980; Thompson and Oldfield, 1986) (Fig. 6a). Application of the imbrication angle methodology may result in other interpretation of the direction of flow (Alva-Valdivia et al., 2005). In this study, only the $\mathrm{K}_{3}$ axes were used to determine flow directions because the $\mathrm{K}_{1}$ axes are approximately perpendicular to the dip direction of the imbrication plane in most AMS stations.

\section{Results}

Directional data of AMS study show a fairly reliable transport pattern in 6 sites inferred by magnetic foliation. These sites situated at Bambili, Mbu Mbengwi and Bamenda show well-defined magnetic fabrics characterized by mostly low plunges of the magnetic lineations ( 1 to $26^{\circ}$ ) and gently inclination of magnetic foliation planes $\left(3\right.$ to $24^{\circ}$ ). The remaining six sites at Bamenda and Sabga cannot used to infer flow directions because they exhibit commonly highly plunging (20 to $80^{\circ}$ ) of magnetic lineations and sharply dipping foliations $\left(52\right.$ to $\left.81^{\circ}\right)$.

Synthetic stereograms of AMS sites at Bamenda, $\mathrm{Mbu}$ and Mbengwi show mildly dipping and steeply dipping magnetic foliations (Fig. 6b). The two AMS stations of Mbengwi locality display normal fabrics (with $\mathrm{K}_{1}$ axis dips at angle of less than $30^{\circ}$, whereas the magnetic foliation plane is subhorizontal i.e. $\mathrm{K}_{3}$ axis is nearly vertical or sharply plunging). In the station GM31, the data shows a well disposition of magnetic foliation plane characterized by the SSW dipping of $24^{\circ}$; the same direction is observable for the magnetic lineation which is approximately parallel to flow. At the station GM32, the magnetic lineation appears transverse to the flow direction, while the $\mathrm{K}_{2}-\mathrm{K}_{1}$ axes are also welldefined with magnetic foliation inclined somewhat $\left(3^{\circ}\right)$ to the SE. At $\mathrm{Mbu}$, the imbrication $\left(19^{\circ}\right)$ of magnetic foliation plane to the WSW is observable in the site GM21. Stations GM28 and GM29 of Bamenda display inverse fabrics (in which $\mathrm{K}_{1}$ axis dips at high angle, generally $>50^{\circ}$ ) whereas Station GM27 exhibits normal fabric with plane of magnetic foliation slightly plunge $\left(11^{\circ}\right)$ to NW. The magnetic lineation for Bamenda seems transverse to flow, i.e., sub-perpendicular to the direction of imbricated magnetic foliation plane.

At Sabga (Fig. 6b), the majority of magnetic foliation planes are steeply dipping $\left(53-75^{\circ}\right)$ in all stations. 


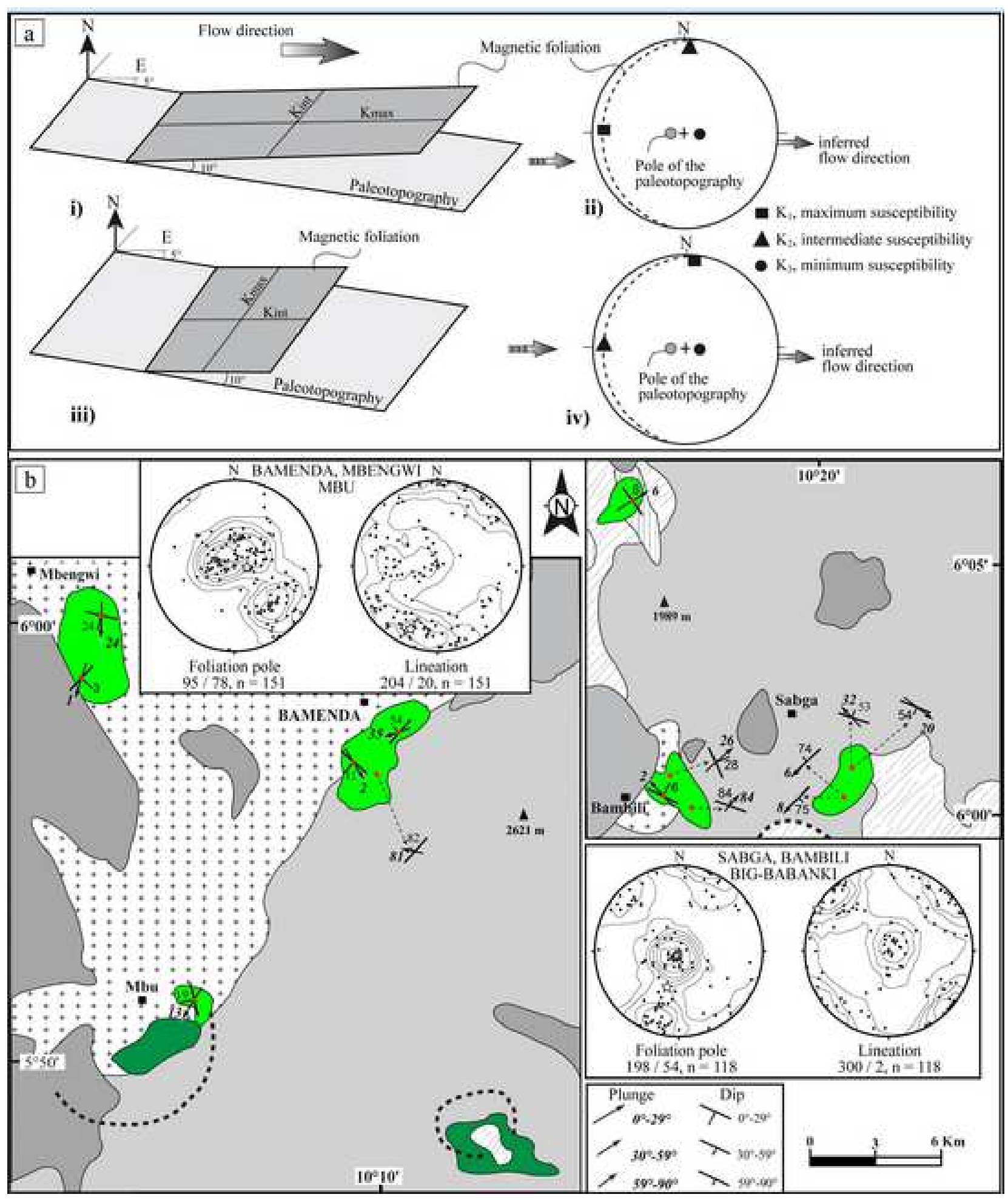

Fig. 6. (a) Conceptual model for imbrication of magnetic foliation in two ideal cases; (i) Magnetic foliation can be imbricated with Kmax axis oriented parallel and (ii) perpendicular to the flow direction and the related (iii, iv) stereoplots of AMS axes. Note the orientation of the magnetic foliation is parallel to the inferred flow direction in both cases (redraw from (Giordano et al., 2008)), (b) Map of magnetic foliation and lineation obtained for accepted AMS sites from Mount Bamenda ignimbritic deposits. Foliation poles and lineation projection diagrams are also presented 
The magnetic foliation plane at Bambili, is well organized and dips moderately $\left(6-28^{\circ}\right)$ to the NE for the stations GM26 and GM24. Concerning the station GM26, magnetic lineations have roughly the same NE direction; the magnetic lineation is on the other hand, transverse to flow direction, at station GM24, i.e., subperpendicular to the imbricated direction of magnetic foliation. At Bambili, site GM33 shows an inverse fabric with subvertical plane of magnetic foliation and lineation. The magnetic foliation dips gently at $6^{\circ}$ to the $\mathrm{NE}$ and the magnetic lineation has the same NE trend at station GM30.

\section{Discussion}

\section{Identification of Emission Centres}

At Bamenda, Mbu and Mbengwi the overall flow direction appears to radiate from the same area, specifically to the Mbu caldera which is the probable emission center. Field indicators around station GM28 in this region also indicate that flow was towards azimuth $46^{\circ}$ (NE).

Flow direction is from NE to $\mathrm{SW}$ at Big Babanki, Sabga and Bambili. Imbricated fiammes around stations GM22 and GM24 are the field indicators indicating that flow pattern was roughly toward azimuth 235 and $222^{\circ}$ respectively. The probable emission center is therefore situated to the $\mathrm{NE}$ of these areas. The probable source of these ignimbrite deposits is then localized in Oku Lake. Finally, based on imbrication of magnetic foliation and field indicators, we conclude that the pyroclastic density current responsible for these deposits was probably generated from Mount Oku caldera concerning ignimbrites of Big Babanki, Sabga and Bambili and from Santa-Mbu caldera for ignimbritic deposits of Bamenda, Mbu and Mbengwi (Fig. 7).

\section{Mapping and Assessment of the Ignimbritic Hazards \\ Mapping}

With the help of outcrop map of exposed ignimbrites at Mt Bamenda and their thickness, we have realized hazard map (Fig. 8) related to surge and pyroclastic flow, or ignimbritic eruptions responsible for these deposits. The region of high risk corresponds to: (i) zone where the deposits of ignimbrites are thick; and (ii) where highly sloping topography area would facilitate the displacement of pyroclastic currents. The regions of medium, moderate and low risk corresponds zones of less thick deposits or to areas where there are no ignimbritic deposits.

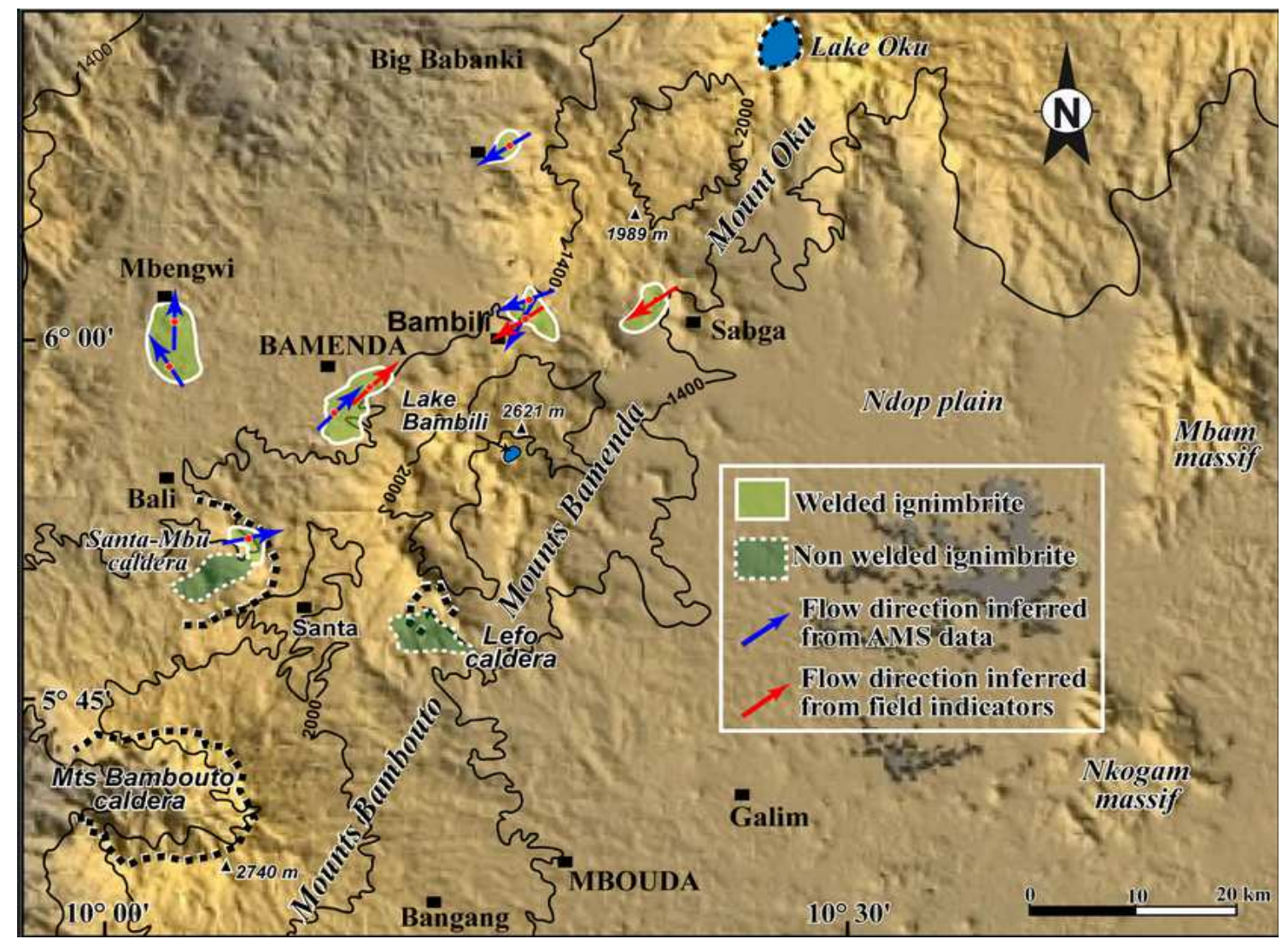

Fig. 7. DEM of Mount Bamenda showing mean flow directions inferred from the orientation of AMS ellipsoids and from field indicators 


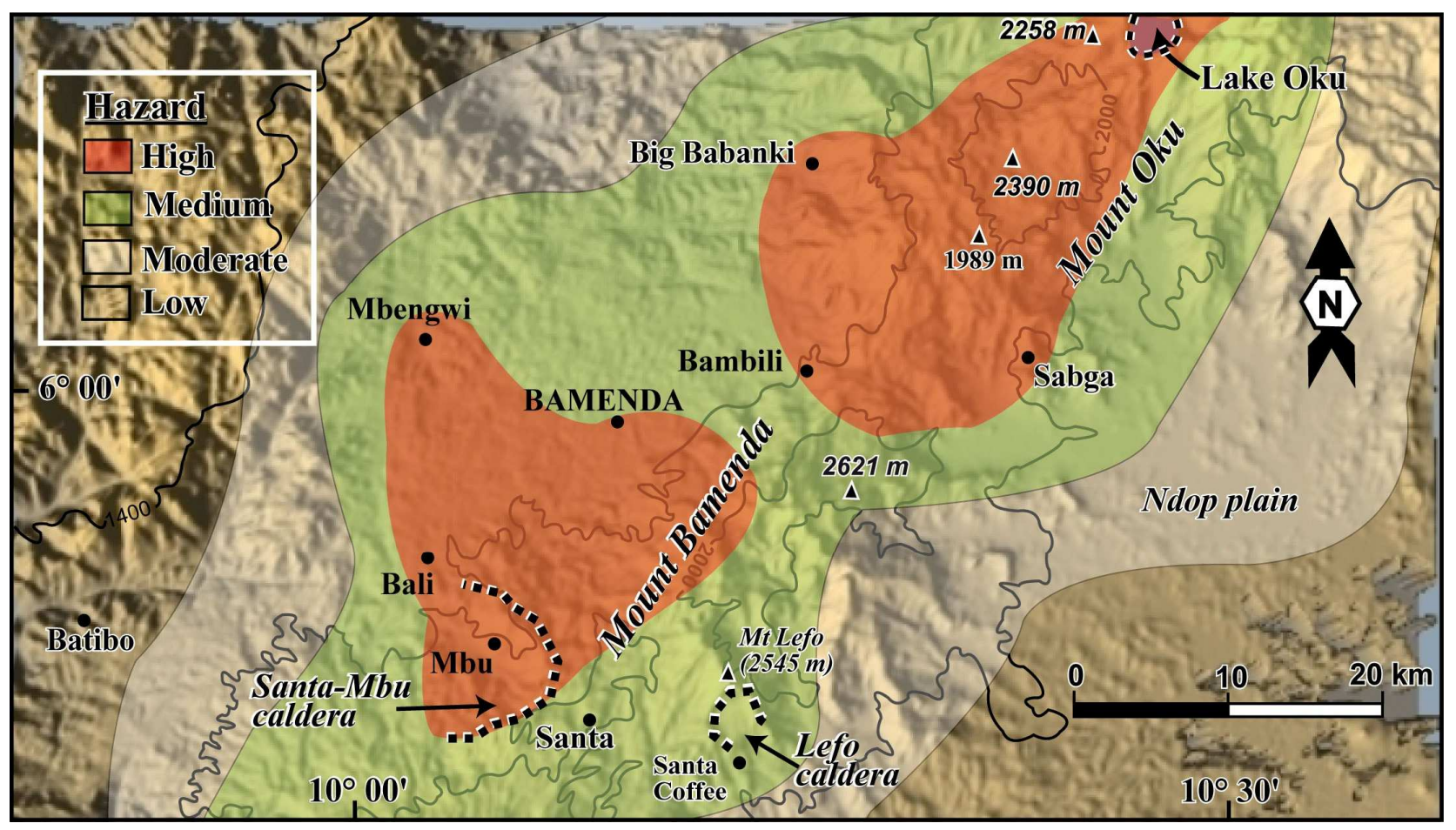

Fig. 8. Hazard map of ignimbritic eruption of Mount Bamenda

Table 2. Average building prices in the Mount Bamenda area (updated in 2014)

Nature of construction (houses and roads)

Clay-brick or wooden house without foundations

Clay-brick or wooden house on a masonry foundation

Mixed construction edifice (sheet metal, wood or breeze blocks)

Breeze blocks house and reinforced concrete

Road
Cost per $\mathrm{m}^{2}$ of housing and road (FCFA). $(1,000$ FCFA $=$ \$US1.76260)

$25,000-35,000$

$45,000-60,000$

75,000

135,000 per storey

Tarred: 2650; not tarred: 650
In the areas where ignimbrites are covered by younger rocks, the boundary of pyroclastic deposits was estimated from multiple quarries (for construction or engineering materials), wells and especially from water drillings (for domestic use), carried out on basaltic and trachytic covers. It should be noted that the areas where the basalt outcrops are densely populated zones because of fertility of soils. The drillings made in these areas are in significant numbers (over 185 listed) and deeper than 45 meters in most cases. The data collected (thickness of pyroclastic deposits) have permitted to estimate in more realistic manner, the surface, the volume of ignimbrites and reliable hazard map.

\section{Assessment}

The Bamenda volcano and its close surrounding are densely populated with more than 750,000 inhabitants. The information for location of the exposed elements and their inventories, followed by the investigation of the different values (economic, environmental, social, human, monetary and strategic) was obtained from the appropriate Cameroonian government departments and concerned administrations completed by field studies. The Cameroonian authorities consider the following elements as being the most important: strategic edifices for management of crisis (health centres, army and security, governance); main centers of financial interest and economic (tourist centres, factories and banks); Population (residential areas and places of sporadic concentrations of people, such as main centers of worship, stadiums, schools and markets); networks and buildings, infrastructures (roads and bridges, housing, power networks, telecommunications relays, water-supply systems,); farmland and natural environment (hydrography and vegetation, industrial plantations and food crops).

Measuring the value of the different element-at-risk was established on information obtained from the several services and organizations responsible for the social system (Table 2). 
It is thus possible to assess by this method of calculation the total capital budget (updated to 2014) of the different element-at-risk within the study area at about 3,063 billion Fcfa or \$US5.4 billion.

\section{Conclusion}

For the determination of flow directions in initially hot volcanic deposits and specifically in deposits of pyroclastic density currents, which are generally isotropic in most outcrops, anisotropy of magnetic susceptibility is a good tool. The high density of population in the Mount Bamenda (more than 750,000 inhabitants) increases the level of risk from future explosive eruptions. This type of study could be extended in this massif on other volcanic product such as basalt, trachyte and rhyolite which cover about $70 \%$ of Bamenda volcano in order to realize a reliable hazard map. In order to refine the hazard zoning map realized in Mt Cameroon (where the last eruptions occurred in 1999 and 2000) (Thierry et al., 2008), the AMS study will also very helpful in this volcano.

\section{Acknowledgment}

This work was stimulated by numerous discussions with the late Professor Nono Alexandre which has suddenly deceased on the morning of 24 July 2012; our posthumously thanks are addressed to him. The authors thank Professor Alain Fotso for accommodation facilities during the field work.

\section{Funding Information}

This work has been partly supported by the SCAC (Service de Coopération et d'Action Culturelle de la France au Cameroun), EGIDE (Centre français pour l'accueil et les échanges internationaux) and the French Government.

\section{Author's Contributions}

Merlin Gountié Dedzo: Designed the study, collected data in the field, made the interpretation and discussion and wrote the manuscript.

Pierre Kamgang: Collected data in the field and made the interpretation, wrote the manuscript and prepare some figures.

Emmanuel Njonfang: Made the interpretation, wrote the manuscript and prepare some figures.

Ghislain Zangmo Tefogoum: Collected data in the field and made the interpretation, wrote the manuscript and prepare some figures.

\section{Ethics}

This article is original. All authors have read and approved the manuscript and no ethical issues involved.

\section{References}

Alva-Valdivia, L.M., J. Rosas-Elguera, T. BravoMedina, J. Urrutia-Fucugauchi and B. Henry et al., 2005. Paleomagnetic and magnetic fabric studies of the San Gaspar ignimbrite, western MexicoConstraints on emplacement mode and source vents. J. Volcanol. Geotherm. Res., 147: 68-80. DOI: 10.1016/j.jvolgeores.2005.03.006

Belousov, A., B. Voight, M. Belousova and A. Petukhin, 2002. Pyroclastic surges and flows from the 8-10 May 1997 explosive eruption of Bezymianny volcano, Kamchatka, Russia. Bull. Volcanol., 64: 455-471. DOI: 10.1007/s00445-002-0222-5

Branney, M.J. and P. Kokelaar, 2002. Pyroclastic Density Currents and the Sedimentation of Ignimbrites. 1st Edn., Geological Society of London, London, ISBN-10: 1862391246, pp: 143.

Burgisser, A. and G.W. Bergantz, 2002. Reconciling pyroclastic flow and surge: The multiphase physics of pyroclastic density currents. Earth Planet. Sci. Lett., 202: 405-418. DOI: 10.1016/S0012-821X(02)00789-6

Calder, E.S., P.D. Cole, W.B. Dade, T.H. Druitt and R.P. Hoblitt et al., 1999. Mobility of pyroclastic flows and surges at the Soufriere hills volcano, Montserrat. Geophys. Res. Lett., 26: 537-540.

Carey, S., 1991. Transport and deposition of tephra by pyroclastic flows and surges. SEPM Special Public., 45: 39-57. DOI: 10.2110/pec.91.45.0039

Cas, R.F.A. and J.V. Wright, 1987. Volcanic Successions Modern and Ancient: A Geological Approach to Processes, Products and Successions. 1st Edn., Springer Science and Business Media, London, ISBN-10: 9400931670 , pp: 528.

Choux, C., 2001. Sedimentation et Segregation Dans Les Ecoulements De Suspensions Concentrees: Approches Experimentales et Applications Volcanologiques. $\mathrm{PhD}$ Thesis, Université Blaise Pascal Clermont-Ferrand II.

Dellino, P. and L. La Volpe, 2000. Structures and grain size distribution in surge deposits as a tool for modelling the dynamics of dilute pyroclastic density currents at La Fossa di Vulcano (Aeolian Islands, Italy). J. Volcanol. Geotherm. Res., 96: 57-78. DOI: 10.1016/S0377-0273(99)00140-7

Druitt, T.H., 1998a. Pyroclastic Density Currents. In: The Physics of Explosive Volcanic Eruptions. Gilbert, J.S. and R.S.J. Sparks (Eds.), Geological Society of London, London, ISBN-10: 1862390207, pp: 145-182.

Druitt, T.H., 1998b. Pyroclastic Density Currents. In: The Physics of Explosive Volcanic Eruptions. Gilbert, J.S. and R.S.J. Sparks (Eds.), Geological Society of London, London, ISBN-10: 1862390207 , pp: 145-182. 
Dunlop, H.M., 1983. Strontium isotope geochemistry and potassium-argon studies on volcanic rocks from the Cameroon Line, West Africa. PhD Thesis, University of Edinburg, Edinburg.

Ellwood, B.B., 1982. Estimates of flow direction for calc-alkaline welded tuffs and paleomagnetic data reliability from anisotropy of magnetic susceptibility measurements: Central San Juan Mountains, southwest Colorado. Earth Planet. Sci. Lett., 59: 303-314. DOI: 10.1016/0012-821X(82)90133-9

Fisher, R.V. and H.U. Schmincke, 1984. Pyroclastic Rocks. 1st Edn., Springer-Verlag, New York, pp: 472.

Fisher, R.V., 1990. Transport and deposition of a pyroclastic surge across an area of high relief: The 18 May 1980 eruption of Mount St. Helens, Washington. Geol. Soc. Am. Bull., 92: 938-954.

DOI:

$10.1130 / 0016-$ 7606(1990) 102<1038:TADOAP > 2.3.CO;2

Fosso, J., J.J. Ménard, J.M. Bardintzeff, P. Wandji and F.M. Tchoua et al., 2005. Les laves du mont Bangou: Une première manifestation volcanique éocène, à affinité transitionnelle, de la Ligne du Cameroun. Comptes Rendus Geosci., 337: 315-325. DOI: 10.1016/j.crte.2004.10.014

Giordano, G., M. Porreca, P. Musacchio and M. Mattei, 2008. The Holocene Secche di Lazzaro phreatomagmatic succession (Stromboli, Italy): Evidence of pyroclastic density current origin deduced by facies analysis and AMS flow directions. Bull. Volcanol., 70: 1221-1236.

DOI: $10.1007 / \mathrm{s} 00445-008-0198-\mathrm{x}$

Gountié Dedzo, M., A. Nédélec, A. Nono, T. Njanko and E. Font et al., 2011. Magnetic fabrics of the Miocene ignimbrites from West-Cameroon: Implications for pyroclastic flow source and sedimentation. J. Volcanol. Geotherm. Res., 203: 113-132. DOI: 10.1016/j.jvolgeores.2011.04.012

Gountié Dedzo, M., P. Kamgang, E. Njonfang, G. Zangmo Tefogoum and D.G. Nkouathio et al., 2015. Remnants Blocks of pyroclastic surge deposits in Bambili, Cameroon Volcanic Line: new insights into the lithostratigraphy of Mount Bamenda. British J. Applied Sci. Technol., 7: 585-596.

DOI: 10.9734/BJAST/ 2015/15958

Henry, B., 1980. Contribution à l'étude des propriétés magnétigues de roches magmatiques des Alpes: Conséquences structurales, régionales et générales Trav Lab Tectonphysique.

Hillhouse, J.W. and R.E. Wells, 1991. Magnetic fabric, flow directions and source area of the lower Miocene Peach Springs Tuff in Arizona, California and Nevada. J. Geophys. Res., 96: 12443-12460.

Jelinek, V., 1981. Characterization of the magnetic fabric of rocks. Tectonophysics, 79: 563-567.

DOI: 10.1016/0040-1951(81)90110-4
Kamgang, P., G. Chazot, E. Njonfang and F.M. Tchoua, 2008. Geochemistry and geochronology of mafic rocks from Bamenda Mountains (Cameroon): Source composition and crustal contamination along the Cameroon Volcanic Line. Comptes Rendus Geosci., 340: 850-857.

DOI: $10.1016 /$ j.crte.2008.08.008

Kamgang, P., E. Njonfang, G. Chazot and F.M. Tchoua, 2007. Géochimie et géochronologie des laves felsiques des monts Bamenda (ligne volcanique du Cameroun). Comptes Rendus Geosci., 339: 659-666. DOI: 10.1016/j.crte.2007.07.011

Kamgang, P., 1986. Contribution à l'étude géochimique et pétrologique du massif de Nkogam (pays Bamoun, Ouest-Cameroun). PhD Thesis, Université de Yaoundé.

Knight, M.D., G.P.L. Walker, B.B. Ellwood and F. Diehl-Jimmy, 1986. Stratigraphy, paleomagnetism and magnetic fabric of the Toba Tuffs: Constraints on the sources and eruptive styles. J. Geophys. Res., B, 91: 10355-10382. DOI: $10.1029 / J B 091$ iB10p10355

Le Pennec, J.L., Y. Chen, H. Diot, J.L. Froger and A. Gourgaud, 1998. Interpretation of anisotropy of magnetic susceptibility fabric of ignimbrites in terms of kinematic and sedimentological mechanisms: An Anatolian case-study. Earth Planet. Sci. Lett., 157: 105-127. DOI: $10.1016 / \mathrm{S} 0012-821 \mathrm{X}(97) 00215-\mathrm{X}$

Lissom, J., 1991. Etude pétrologique des laves alcalines $\mathrm{du}$ massif d'Oku: Un ensemble volcanique de la "Ligne du Cameroun". Université Pierre et Marie Curie.

MacDonald, W.D. and H.C. Palmer, 1990. Flow directions in ash-flow tuffs: A comparison of geological and magnetic susceptibility measurements, Tshirege member (upper Bandelier Tuff), Valles caldera, New Mexico, USA. Bull. Volcanol., 53: 45-59. DOI: 10.1007/BF00680319

Mellors, R.A., R.B. Waitt and D.A. Swanson, 1988. Generation of pyroclastic flows and surges by hotrock avalanches from the dome of Mount St. Helens volcano, USA. Bull. Volcanol., 50: 14-25. DOI: 10.1007/BF01047505

Moundi, A., P. Wandji, J.M. Bardintzeff, J.J. Ménard and L.C. OkomoAtouba et al., 2007. Les basaltes éocènes à affinité transitionnelle $\mathrm{du}$ plateau Bamoun, témoins d'un réservoir mantellique enrichi sous la ligne volcanique du Cameroun. Comptes Rendus Geosci., 339: 831-837. DOI: $10.1016 /$ j.crte.2007.04.001

Nono, A., B. Déruelle, D. Demaiffe and R. Kambou, 1994. Tchabal Nganha volcano in Adamawa (Cameroon): Petrology of a continental alkaline lava series. J. Volcanol. Geotherm. Res., 60: 147-178. DOI: 10.1016/0377-0273(94)90066-3 
Nzolang, C., H. Kagami, P. Nzenti and F. Hotz, 2003. Geochemistry and preliminary $\mathrm{Sr}-\mathrm{Nd}$ isotopic data on the Neoproterozoic granitoids from the Bantoum Area, West Cameroon: Evidence for a derivation from a Paleoproterozoic to Archean crust. Polar Geosci., 16: 196-226.

Ort, M.H., 1993. Eruptive processes and caldera formation in a nested down sagcollapse caldera: Cerro Panizos, central Andes Mountains. J. Volcanol. Geotherm. Res., 56: 221-252. DOI: 10.1016/0377-0273(93)90018-M

Palmer, H.C. and W.D. MacDonald, 1999. Anisotropy of magnetic susceptibility in relation to source vents of ignimbrites: Empirical observations. Tectonophysics, 307: 207-218. DOI: 10.1016/S0040-1951(99)00126-2

Schminke, H.U., 2004. Volcanism. 1st Edn., Springer Science and Business Media, Berlin, ISBN-10: 3540436502, pp: 324.

Seaman, S.J., W.C. Mcintosh, J.W. Geissman, M.L. Williams and W.E. Elston, 1991. Magnetic fabrics of the Bloodgood Canyon and Shelley Peak Tuffs, southwestern New Mexico: Implications for emplacement and alteration processes. Bull. Volcanol., 53: 460-476. DOI: 10.1007/BF00258185

Suh, C.E., R.S.J. Sparks and J.G. Fitton, 2003. The 1999 and 2000 eruptions of Mt Cameroon: eruption behavior and petrochemistry of lava. Bull Volcanol 65: 267-281. DOI: 10.1007/s00445-002-0257-7

Thompson, R. and F. Oldfield, 1986. Environmental Magnetism. 1st Edn., Allen and Unwin, London, pp: 227.

Thierry, P., L. Stieltjes, E. Kouokam, P. Nguéya and P.M. Salley, 2008. Multi-hazard risk mapping and assessment on an active volcano: The GRINP project at Mount Cameroon. Nat Hazards, 45: 429-456. DOI: $10.1007 / \mathrm{s} 11069-007-9177-3$
Toteu, S.F., W.R. Van Schmus, J. Penaye and A. Michard, 2001. New U-Pb and Sm-Nd data from north-central Cameroon and its bearing on the prePan African history of central Africa. Precamb. Res., 108: 45-73. DOI: 10.1016/S0301-9268(00)00149-2

Valentine, G.A. and R.V. Fisher, 2000. Pyroclastic Surges and Blasts. In: Encyclopedia of Volcanoes, Sigurdsson, H. (Ed.), Academic Press, San Diego, ISBN-10: 012643140X, pp: 571-580.

Walker, G.P.L., 1983. Ignimbrite types and ignimbrite problems. J. Volcanol. Geotherm. Res., 17: 65-88. DOI: 10.1016/0377-0273(83)90062-8

Wilson, C.J.N. and B.F. Houghton, 2000. Pyroclast Transport and Deposition. In: Encyclopedia of Volcanoes, Sigurdsson, H. (Ed.), Academic Press, San Diego, ISBN-10: 012643140X, pp: 545-554.

Wilson, C.N.J., 1997. Emplacement of Taupo ignimbrite. Nature, 385: 306-307. DOI: $10.1038 / 385307 \mathrm{a} 0$

Wolff, J.A. and J.V. Wright, 1981. Rheomorphism of welded tuffs. J. Volcanol. Geotherm. Res, 10: 13-34. DOI: 10.1016/0377-0273(81)90052-4

Wolff, J.A., B.B. Ellwood and S.D. Sachs, 1989. Anisotropy of magnetic susceptibility in welded tuffs: Application to a welded-tuff dyke in the tertiary Trans-Pecos Texas volcanic province, USA. Bull. Volcanol., 51: 299-310.

DOI: $10.1007 / \mathrm{BF} 01073518$ 